\title{
Trends Of Accounting Restatements During The Period 2000-2007 And Big Four/Five Auditors
}

Kam C. Chan, Pace University, USA

Barbara R. Farrell, Pace University, USA

Picheng Lee, Pace University, USA

\begin{abstract}
The objective of this study is to provide further analysis on the trends of accounting restatements during the period 2000-07 and the role of Big four/five auditors. Given the changes in regulatory environment after the enforcement of Section 404 of the Sarbanes-Oxley Act, we find that there is a significant increase in restatements in recent years. We also find that restatements being disclosed in recent years are more serious, however, they are disclosed on a more timely basis. Consistent with the general belief that Big four/five auditors are better quality auditors, we find that they are associated with shorter restatement disclosure lags. In addition, restatements with positive financial statement effects are more likely to be disclosed sooner than those with negative effects.
\end{abstract}

Keywords: Sarbanes-Oxley; restatement; and auditors

\section{INTRODUCTION}

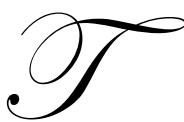

he corporate scandals of the early $21^{\text {st }}$ century seriously affected investor confidence in the capital markets. In an effort to address these problems, the U.S. Congress passed the Sarbanes-Oxley Act of 2002 (SOX). Section 404 of SOX is considered by many as the most important aspect of the Sarbanes-Oxley Act ${ }^{1}$. Under Section 404, the management and a firm's external independent auditor are required to report on the effectiveness of the firm's internal control on financial reporting. The Securities and Exchange Commission (SEC) requires all U.S. public companies that are considered as accelerated filers to report on the effectiveness of their internal control over financial reporting for fiscal years ending on or after November 15, 2004. Accelerated filers are generally defined as companies with at least $\$ 75$ million in public equity float. The SEC also requires foreign large accelerated filers to provide both management and auditor Section 404 reports for fiscal years ending on or after July 15, 2006. Large accelerated filers are generally defined as firms with public equity float of at least $\$ 700$ million. Non-accelerated filers are still not yet required to conduct Section 404 review given the high compliance costs.

Several studies have examined the increase in audit fees due to the expanded audit effort required under a Section 404 review. For example, Eldridge and Kealey (2005) find an average increase of $100 \%$ in audit fees among banks, and Raghunandan and Rama (2006) report an average increase of $86 \%$ in audit fees among industrial firms in 2004. Chan et al. (2008) find an average increase of $74 \%$ in audit fees among foreign firms listed on major U.S. exchanges in their first year of Section 404 compliance. Most interestingly, Benoit (2006) and Chan et al. (2008) also report that there are significant increases in audit fees even for the non-accelerated filers that are not yet required to comply with Section 404. These findings suggest that audits are generally more extensive for all firms given the stricter regulatory environment since 2004.

\footnotetext{
${ }^{1}$ Don Nicolaisen, the then chief accountant at the SEC, suggested that Section 404 could be the most important aspect of Sarbanes-Oxley, and he also stated that Section 404's "overriding objective is to provide comfort, to provide assurance that the process is there to enable accurate, reliable financial reporting ... for the investor" (PR Newswire, January 12, 2005).
} 
There is a substantial increase in the number of accounting restatements in recent years. Many have attributed the increased number of restatements to the general change in audit efforts since the passage of SOX, and Section 404 in particular (Solomon 2007). The Government Accountability Office (GAO) reports that the number of financial restatements among public companies have increased from 3.7 percent of firms listed on major U.S. exchanges in 2002 to about 6.8 percent in late 2005 (GAO 2006). Turner and Weirich (2006) also document that the number of financial restatements among U.S. firms has increased to 613 in 2004 and jumped to 1,195 in 2005, most likely due to the more extensive internal control reviews conducted in 2004.

The objective of this study is to further analyze the association between accounting restatements in recent years and the role of Big four/five auditors. Specifically, we examine the numbers of accounting restatements disclosed during the period 2000-07 and whether there are more serious restatements in recent years. We also examine if the restatements are disclosed more timely in recent years. Finally, we analyze if the patterns of accounting restatements are different between Big four/five and non-Big four/five auditors, and between positive and negative financial statement effects of the restatements. One of the foremost criticisms of Section 404 is the additional amount of audit efforts. If the additional audit efforts lead to more timely discovery and disclosure of accounting errors, the additional work represents important benefits of $\mathrm{SOX}^{2}$.

This study is organized as follows. Section 2 discusses the related literature and research objectives. Section 3 describes the research design and summarizes the empirical findings. Section 4 presents concluding comments.

\section{RELATED LITERATURE AND RESEARCH OBJECTIVES}

Prior studies have examined different aspects of accounting restatements. Palmrose et al. (2004) and GAO (2006) find significant negative stock price reactions to announcements of accounting restatements. For example, GAO (2006) reports an average of $2 \%$ decline in stock price in the three trading days around the initial restatement announcements. Feldman, Livnat, and Segal (2008) further find that the stock prices of firms announced restatements continue to drift downward even after the initial announcements. Accounting restatements also have significant impacts on management turnover and other firms in the industry. Gleason, Jenkins, and Johnson (2008) find that restatement announcements of the restating firms also induce negative stock price reactions to non-restating firms in the same industry. The extent of the stock price declines of the non-restating firms is greater for nonrestating firms with higher industry-adjusted accruals. This suggests that investors revise their perceptions of the quality of accounting practices of the non-restating firms downward if these firms are more likely to have earnings management. This finding is consistent with the results in Desai, Krishnamurthy, and Venkataraman (2006) that short sellers would accumulate short positions in restating firms several months before the restatements were announced. The average increase in short positions is larger for restating firms with higher level of accruals prior o the restatements. Aier et al. (2005) find that firms are less likely to have accounting restatement if their chief financial officers (CFO) have more work experiences as CFOs and have Certified Public Accountant or Master in Business Administration credentials. On the other hand, Desai, Hogan, and Wilkins (2006) find that firms are more likely to have at least one senior manager (chairman, chief executive officer, or president) change within two years of restatement announcements. In addition, the replaced senior managers faced deterioration in the quality of their new employments in terms of being re-hired by smaller firms and with lower compensation.

The substantial increase in accounting restatements in recent years is often considered as a result of the passage of Section 404. For example, Eldridge and Kealey (2005) find an average increase of $100 \%$ in audit fees among U.S. banks in 2004. Likewise, Raghunandan and Rama (2006) report an average increase of 86\% in audit fees among U.S. industrial firms in 2004. Consistent with the increases in audit fees, Ettredge, Li, and Sun (2006) find significant audit delays due to Section 404 reviews. Chan, Farrell, and Lee (2008) report that firms reporting ineffective internal controls under Section 404 often also have accounting restatements caused by the material internal control weaknesses. Chan, Lee, and Seow (2008) also find that even with the significant increase in audit

\footnotetext{
${ }^{2}$ The examination of the overall net benefit of SOX and Section 404 is beyond the scope of this study. To determine the overall net benefit of SOX and Section 404, other potential costs and benefits such as the direct compliance costs, opportunity cost of managerial efforts, and deterrent on potential earnings management should be also considered.
} 
fees, management and auditors failed to identify material internal control weaknesses of some firms. As a result, management and auditors have to amend their Section 404 opinions concluding that firms indeed have ineffective internal controls. Moreover, firms often have to restate their financial statements because of the amended Section 404 opinions. In addition, Section 404 has significant effects on the audit efforts among smaller firms that do not have yet to comply with Section 404. Benoit (2006) and Chan et al. (2008) report significant increase in audit fees among firms that are not required to conduct Section 404 reviews. This reflects the general stricter regulatory environment since Section 404 becomes effective in 2004.

This study examines whether there is a significant increase in restatement in recent years due to the effects of Section 404. We then examine if firms with Big four/five auditors are more likely to report restatements and report the restatements more timely since Big four/five auditors are generally considered as having better quality in disclosure decisions (Geiger and Rama 2006; Francis and Wang 2008) ${ }^{3}$. We also examine if restatements with positive financial statement effects are more likely to be reported sooner than those with negative financial statement effects since management are more likely to report good news early and bad news late (Bagnoll, Kross, and Watts 2002).

\section{RESEARCH DESIGN AND FINDINGS}

A sample of restatements disclosed in 2000-2007 is collected from the Audit Analytics database. Restatements related to accounting rule application failures, financial fraud, irregularities and misrepresentations, and errors related to accounting and clerical applications are included in our sample. A firm is considered as having a Big four/five auditor if the firm has a Big four/five auditor at the time of restatement disclosure. Data from Audit Analytics also reports if the restatements have net positive or negative effects to financial statement numbers. We define the restatement period as the number of calendar days between the beginning date and the ending date of the restatement period. We also define restatement disclosure lag as the number of calendar days between the ending date of the restatement period and the restatement disclosure date ${ }^{4}$. The restatement disclosure date is the earliest SEC filing date or press release related to the restatement as reported in Audit Analytics.

Table 1

Summary statistics of accounting restatements in 2000-2007

Total number of restatements $=\mathbf{8 , 5 9 1}$

\begin{tabular}{|c|c|c|c|c|c|}
\hline Year & $\begin{array}{c}\text { \# of } \\
\text { restatements }\end{array}$ & $\begin{array}{l}\text { Positive } \\
\text { effects }\end{array}$ & $\begin{array}{l}\text { Negative } \\
\text { effects }^{\mathrm{c}}\end{array}$ & $\begin{array}{l}\text { Big four/five } \\
\text { auditors }\end{array}$ & $\begin{array}{c}\text { non-Big four/five } \\
\text { auditors }\end{array}$ \\
\hline 2000 & 476 & $\frac{9}{9}$ & 467 & 255 & $\frac{221}{21}$ \\
\hline 2001 & 620 & 39 & 581 & 346 & 274 \\
\hline 2002 & 737 & 47 & 690 & 452 & 285 \\
\hline 2003 & 930 & 76 & 854 & 615 & 315 \\
\hline 2004 & 1061 & 87 & 974 & 662 & 399 \\
\hline 2005 & 1619 & 191 & 1428 & 941 & 678 \\
\hline 2006 & 1847 & 218 & 1629 & 725 & 1122 \\
\hline 2007 & 1301 & 135 & 1166 & 503 & 798 \\
\hline
\end{tabular}

a: number of accounting restatements reported in Audit Analytics.

b: number of accounting restatements with net positive effects to financial statements.

c: number of accounting restatements with net negative effects to financial statements.

$\mathrm{d}$ : number of accounting restatements from firms audited by Big four/five accounting firms.

e: number of accounting restatements from firms audited by non-Big four/five accounting firms.

A total of 8,591 restatements are included in our final sample. Table 1 provides the descriptive statistics of the restatements. The number of restatements disclosed in each year has increased gradually from 476 in 2000 to

\footnotetext{
${ }^{3}$ Arthur Anderson is considered as one of the Big 5 auditors in 2000-02 in the data.

${ }^{4}$ In the few cases that the ending dates of the restatement period are after the restatement disclosure dates, we define the disclosure lag as zero. We also deleted a few isolated cases that Audit Analytics doesn't report whether the restatements have positive or negative financial statement effects.
} 
1,061 in 2004 with a big jump to 1,619 in 2005 probably due to the effects of Section 404 review. About $91 \%$ of the restatements have net negative effects on financial statement numbers. The total number of restatements associated with Big four/five or non-Big four/five auditors are about the same. One interesting pattern is that there are more restatements associated with Big four/five auditors in 2000-05. However, the trend has reversed in 2006-07 with more restatements associated with non-Big four/five auditors. This is consistent with the findings in the literature that Section 404 reviews among larger firms has caused more audit efforts even among smaller firms that are not required to comply with Section 404.

Table 2 reports the descriptive statistics for restatement periods and restatement disclosure lag. Panel A shows that the length of the restatement periods has increased in recent years and the increase is larger among restatements associated with Big four/five auditors. Panel B suggests that the time lag between the restatement ending period and restatement disclosure date has reduced in recent years. Comparing the disclosure lags between the restatements associated with Big four/five and non-Big four/five auditors, restatements associated with Big four/five auditors always have a shorter average disclosure lag.

Table 2

Restatement periods and disclosure lags

\begin{tabular}{|c|c|c|c|}
\hline \multicolumn{4}{|c|}{ Panel A: average \# of calendar days covered in the restatement period } \\
\hline Year & $\underline{\text { All restatements }}$ & $\begin{array}{l}\text { Big four/five } \\
\text { auditors }^{\text {a }}\end{array}$ & $\begin{array}{l}\text { Big four/five } \\
\text { auditors }\end{array}$ \\
\hline$\overline{2000}$ & 529 & 521 & 538 \\
\hline 2001 & 468 & 490 & 440 \\
\hline 2002 & 525 & 585 & 429 \\
\hline 2003 & 539 & 584 & 450 \\
\hline 2004 & 602 & 684 & 467 \\
\hline 2005 & 747 & 883 & 559 \\
\hline 2006 & 714 & 1063 & 489 \\
\hline 2007 & 651 & 882 & 506 \\
\hline \multicolumn{4}{|c|}{ Panel B: average \# of calendar days from the end of the restatement period to the restatement disclosure date } \\
\hline Year & All restatements & $\begin{array}{c}\text { With Big four/five } \\
\text { auditors }^{\mathrm{a}}\end{array}$ & $\begin{array}{c}\text { With non-Big four/five } \\
\text { auditors }^{\mathrm{b}}\end{array}$ \\
\hline$\overline{2000}$ & 286 & 244 & 335 \\
\hline 2001 & 316 & 277 & 366 \\
\hline 2002 & 267 & 245 & 303 \\
\hline 2003 & 314 & 307 & 327 \\
\hline 2004 & 288 & 281 & 301 \\
\hline 2005 & 234 & 205 & 273 \\
\hline 2006 & 267 & 255 & 275 \\
\hline 2007 & 289 & 281 & 294 \\
\hline
\end{tabular}

a: accounting restatements from firms audited by Big four/five accounting firms.

b: accounting restatements from firms audited by non-Big four/five accounting firms.

We also conduct regression analysis on the restatement period and restatement disclosure lag using the following model:

Restatement period ${ }_{\mathrm{i}}$ or Restatement disclosure $\operatorname{lag}_{\mathrm{i}}$

$=\beta_{0}+\beta_{1}$ Yeari $+\beta_{2}$ Big four/five ${ }_{i}+\beta_{3}$ Postive Effect $_{i}+e_{i}$

where

Year $_{\mathrm{i}}=$ the calendar year of the restatement disclosure $;$ Year $=2000$ to 2007.

Big four/five $\mathrm{i}_{\mathrm{i}}=1$ if restatement $\mathrm{i}$ is associated with a Big four/five auditor; $=0$ otherwise.

Positive Effect $_{\mathrm{i}}=1$ if restatement $\mathrm{i}$ has a net positive effect to financial statements; $=0$ otherwise. 
Table 3 reports the results of the regression analysis on the restatement period. Model (1) shows that the coefficients on Year and Big four/five are both significantly positive. Positive Effect is added in Model (2) and the coefficient is negative and significant. These findings suggest that restatements disclosed in more recent years are generally more serious problem in term of the length of the restatement periods. The results also show that restatements associated with Big four/five auditors have longer restatement periods as Big four/five auditors could be more forceful in restatement decisions. The negative coefficient on Positive Effect indicates that restatements with positive effects on financial statements covered shorter restatement periods than that of the restatements with negative effects. Models (3) and (4) re-examine the analysis using an indicator variable, Year 04_07, for the 200407 period. Consistent with the findings in Models (1) and (2), the coefficients on Year 04_07 in Models (3) and (4) are significantly positive. This suggests that restatements disclosed in 2004-07 have longer restatement period when compared to the restatements disclosed in 2000-03.

Table 3

Results of regression analysis on restatement period Dependent variable $=$ restatement period Sample size $=8591$

\begin{tabular}{|c|c|c|c|c|}
\hline Model & (1) & (2) & (3) & (4) \\
\hline \multicolumn{5}{|l|}{ Variables: } \\
\hline Intercept & $-91366.00 * * *$ & $-92888.00 * * *$ & $343.43 * * *$ & $346.66 * * *$ \\
\hline Year & $45.82 * * *$ & $46.58 * * *$ & & \\
\hline Year 04_07 & & & $205.70 * * *$ & $208.60 * * *$ \\
\hline Big four/five & $294.28 * * *$ & $295.29 * * *$ & $288.28 * * *$ & $289.11 * * *$ \\
\hline Positive effect & & $-62.87 * * *$ & & $-60.45^{* * * *}$ \\
\hline Adj. $R^{2}$ & 0.0743 & 0.0751 & 0.0752 & 0.0760 \\
\hline F-statistic & $345.78 * * *$ & $233.61 * * *$ & $350.46 * * *$ & $236.50 * * *$ \\
\hline
\end{tabular}

**, *** Significant at 5\% and $10 \%$ level, respectively in two-tailed test.

Restatement period = \# of calendar days from the beginning of the restatement period to the end of the restatement period.

Year $=$ a trend variable of 2000-07 corresponding to the year that the disclosure of each restatement was made.

Year 04_07 = 1 if the restatement was disclosed in 2004-07; = 0 otherwise.

Big four/five $=1$ if the firm has a Big four/five auditor; $=0$ otherwise

Positive effect $=1$ if the net effect of the restatement to financial statement is positive; $=0$ otherwise .

Table 4

Results of regression analysis on restatement disclosure lag Dependent variable $=$ restatement disclosure lag Sample size $=\mathbf{8 5 9 1}$



**, *** Significant at 5\% and $10 \%$ level, respectively in two-tailed test.

Restatement disclosure lag = \# of calendar days from the end of the restatement period to the restatement disclosure date.

Table 4 reports the regression results on restatement disclosure lag. In Models (1) and (2), the coefficients on Year, Big four/five, and Positive Effect are all negative and statistically significant. This indicates that the restatements are disclosed more timely in more recent years and the disclosures are even more timely among firms with Big four/five auditors. This is consistent with the stronger regulatory environment in more recent years and 
with the notion that Big four/five auditors are of better quality in terms of the association with more timely firm disclosure. Consistent with findings in the literature that firms are more likely to report good news sooner than bad news, restatements with positive financial statement effects, have shorter disclosure lag. Models (3) and (4) replace the variable Year with the indicator variable of Year 04_07 and provide similar conclusions that restatements disclosed in 2004-07 are disclosed more timely than the restatements disclosed in 2000-03.

\section{CONCLUSIONS}

This study examines the trends of accounting restatements during the period 2000-07. Given the changes in regulatory environment after the passage of Sarbanes-Oxley Act, and Section 404 in particular, we find that there is a significant increase in restatements in more recent years. Moreover, the restatements disclosed in more recent years are more serious restatements in terms of longer restatement periods. However, the restatements disclosed in recent years are more timely in terms of short disclosure lag. We find the Big four/five auditors are associated with longer restatement periods and shorter disclosure lags. The number of restatements disclosed in 2007 is less than that of 2005 and 2006. Furthermore, we also find that the restatements disclosed in 2007 have shorter restatement period when compared to that of 2006 for the overall sample and firms with Big four/five auditors. This may be indications that Section 404 has positive effects in forcing firms to disclose previous accounting errors and the number of restatements might have peaked in 2006.

\section{AUTHOR INFORMATION}

Kam C. Chan is a professor of accounting at the Lubin School of Business at Pace University. He received his $\mathrm{Ph} . D$. degree from the University of South Carolina in 1991. His research interests include capital market research in financial accounting, corporate finance, and investments. He has published in many top journals such as Accounting, Organizations and Society, Auditing: A Journal of Practice and Theory, Journal of Accounting and Economics, Journal of Business Finance and Accounting, and Review of Quantitative Finance and Accounting.

Barbara Farrell is an associate professor at Pace University. Dr. Farrell has extensive experience teaching in corporate classes. These classes included CMA review and computer application classes for corporations such as IBM, Readers Digest and many others. Dr. Farrell has a BBA and MBA from Pace University and an EdD from Columbia University. She is a CPA. Prior to entering education, Dr. Farrell was an auditor in both "Big 8" public accounting and in the private sector specializing in computer auditing. Dr. Farrell has published in CPA Journal, Journal of Forensic Accounting, and Auditing: A Journal of Practice and Theory.

Picheng Lee is an associate professor of accounting at Pace University. He is also a certified management accountant (CMA) and a member of editorial board of the International Journal of Accounting and Information Management. Dr. Lee obtained his Ph. D. degree from Rutgers University in 2000 and joined Pace University since then. Dr. Lee's research interest is in financial accounting and auditing. His papers has been published in various journals including Auditing: A Journal of Practice and Theory, Journal of Accounting, Auditing, and Finance, Journal of International Accounting Research, Journal of Forensic Accounting, and Review of Quantitative Finance and Accounting.

\section{REFERENCES}

1. Aier, J., Comprix, J., Gunlock, M., and Lee, D. 2005. The financial expertise of CFOs and accounting restatements. Accounting Horizons 19: 123-135.

2. Bagnoll, M., Kross, W., and Watts, S. 2002. The information in management's expected earnings report date: a day late, a penny short. Journal of Accounting Research, pp. 1275-1296.

3. Benoit, B. 2006. The impact of Sarbanes-Oxley on the real estate industry. Banker \& Tradesman, February 27, available at www.insidesarbanesoxley.com/sarbanes-oxley-resources/lord-benoit/.

4. Chan, K., Farrell, B., and Lee, P. 2008. Earnings management of firms reporting material internal control weaknesses under Section 404 of the Sarbanes-Oxley Act. Auditing: A Journal of Practice \& Theory (forthcoming). 
5. _ L L_ Lee, P., and Seow, G. 2008. Why did management and auditors fail to identify ineffective internal controls in their initial Section 404 reviews? Review of Accounting and Finance 9: 338-354.

6. __ Jacob, P., Lee, P. and Seow, G. 2009. The effects of Section 404 of Sarbanes-Oxley Act of 2002 on the audit fees of foreign firms listed on U.S. exchanges. Working paper, Pace university and University of Connecticut.

7. Desai, H., Krishnamurthy, S., and Venkataraman, K. 2006. Do short sellers target firms with poor earnings quality? Evidence from earnings restatements. Review of Accounting Studies 11: 71-90.

8. _ Hogan, C., and Wilkins. 2006. The reputational penalty for aggressive accounting: Earnings restatements and management turnover. The Accounting Review 81: 83-112.

9. Eldridge, S., Kealey, B., 2005. SOA Attestation: What are the initial costs for banks? Bank Accounting \& Finance 19: 3-12.

10. Francis, J. and Wang, D. 2008. The joint effect of investor protection and Big 4 audits on earnings quality around the world. Contemporary Accounting Research 25: 157-191.

11. Geiger, M. and Rama, D. 2006. Audit firm size and going-concern reporting accuracy. Accounting Horizons 20: 1-17.

12. Gleason, C., Jenkins, N., and Johnson, W. 2008. The contagion effects of accounting restatements. The Accounting Review 83: 83-110.

13. Palmrose, Z., Richardson, V., and Scholz, S. 2004. Determinants of market reactions to restatement announcements. Journal of Accounting and Economics 37: 59-90.

14. PR Newswire. 2005. Investors' perspective: The focus of conference on new Section 404 internal control reporting. January 12.

15. Raghunandan, K., Rama, D. 2006. SOX Section 404 material weakness disclosures and audit fees. Auditing: A Journal of Practice \& Theory 25: 99-114.

16. Solomon, D. 2007. Treasury target financial fixes; Paulson sets study on rise in corporate restatements and the impact on markets. The Wall Street Journal (Eastern edition), New York, NY, May 18, 2007, page A2.

17. Turner, L. and Weirich, T. 2006. A closer look at financial statement restatements. The CPA Journal 76: $12-23$.

18. United States Government Accountability Office (GAO) 2006. Financial Restatements: Update of public company trends, market impacts, and regulatory enforcement activities. GAO-06-678. Washington, D.C. Government Printing Office. 
Journal of Business \& Economics Research-August, 2009

Volume 7, Number 8

\section{NOTES}

